Kelaniya Journal of Human Resource Management

Volume 11, Number 02 - July 2016

DOI: http://doi.org/10.4038/kjhrm.v11i2.33

\title{
Welfare Facilities and Job Satisfaction: A Study of Operational Level Employees in the Apparel Industry of Sri Lanka
}

\author{
M. V. S. Mendis \\ Department of Human Resource Management, Faculty of Commerce and \\ Management, University of Kelaniya, Sri Lanka \\ virangisonali2@gmail.com
}

\begin{abstract}
People become the most important asset to any company in today's business world. Unlike physical assets, human assets can be developed, improved and motivated to achieve the goals and objectives of an organization. Further satisfied employees will make the organization to achieve its goals and objectives smoothly. Therefore keep employees satisfy is a necessity for any organization. The prime focus of this study was to investigate the relationship between welfare facilities and operational level employees' job satisfaction in the apparel industry of Sri Lanka. This study empirically evaluated four independent variables (medical facilities, canteen facilities, loan facilities and housing facilities) and their relationship to the job satisfaction of operational level employees in the apparel industry of Sri Lanka. The sample consists of 100 operational level employees in the apparel industry of Sri Lanka. The data collection was done by using a self-administrated structured questionnaire. The results indicated that medical facilities, canteen facilities, loan facilities and housing facilities variables were positively and significantly correlated with job satisfaction variable. But those relationships were not much strong.
\end{abstract}

Keywords: Welfare Facilities, Job Satisfaction, Operational Level Employees

\section{Introduction}

Human Resource Management (HRM) consists of eighteen functions such as " Job analysis, job design, human resource planning, recruitment, selection, hiring, induction, performance management, training and development, pay management, career management, welfare management, grievance 
management, health and safety management, industrial relation, employee movement management, disciplinary management" (Opatha, 2009). Employee welfare management is one of important functions of HRM. Employee's welfare package s help to attract and retain suitably qualified employees for the organization. Employee welfare can be defined as "Providing facilities and comforts to employee of an organization, so that they will be able to lead a better level of living" (Opatha, 2009, p. 614). According to Opatha (2009, p. 616) HRM function of employee welfare should not be treat as a function of less importance. Though the organization has to spend a considerable amount of money and other resource, employee welfare is often an investment that is conductive to organizational success and progress of success. Strategic reasons for offering benefits include attracting and retaining employees, improving the company's images, and enhancing job satisfaction (Armstrong, 1996). Hoppock (1935) defined that job satisfaction as "any combination of psychological, physiological and environmental circumstances that cause a person truthfully to say I am satisfied with my job" (p. 47). The employees who are satisfied are the biggest assets to an organization as such employees who are dissatisfied are the biggest liabilities (Baghaei, 2011, p. 119).

The objective of this study is to examine the relationship between welfare facilities and operational level employees' job satisfaction in the apparel industry of Sri Lanka. According to De Souza (2009, p. 40) the employee welfare measures provided in an organization affect the attitudes of employees' towards work. Employee welfare facilities satisfy the needs of the employees, which can improve their working life, family life and overall welfare. Various studies by researchers (De Souza, 2009; Reddy, 2012) have explored the employee welfare facilities provided by organizations and determined its influence on job satisfaction. However, there is a gap in the empirical knowledge available in Sri Lanka with regard to the impact of welfare facilities on job satisfaction. This study therefore seeks to broaden the scope of research in this area in the Sri Lankan context. 


\section{Literature Review}

\subsection{Employee Welfare Facilities}

According to Schuler (1981) welfare facilities defined as "an indirect compensation". He further mentioned that almost all organizations offer some form of indirect compensation - also known as fringe benefits or supplemental compensation. Punekar, Deodhar and Sankaran (2004) defined welfare facilities as, "anything done for the comfort and improvement, intellectual and social, of the employees over and above the wages paid, which is not a necessity of the industry" (p. 24). Hence, the term denotes the adoption of measures to promote the physical, social, psychological and general well-being of the working population. Welfare work in any industry aims, or should aim, at improving the working and living conditions of workers and their families.

The concept of labor welfare varies from time to time, region to region, industry to industry and country to country, depending upon various factors such as educational level, social customs, and degree of industrialization and the general standard of socio-economic development. Employee welfare implies the setting up to minimum desirable standards and the provisions of facilities like health, food, clothing, housing, medical assistance, education, insurance, job security, recreation, etc. such facilities enable the worker and his family to lead a good work life, family life \& social life. Employee welfare measures are an effort towards revolving the industrial worker of his worries and making them happy. Employee welfare can be also defined as "Providing facilities and comforts to employee of an organization, so that they will be able to lead a better level of living" (Opatha, 2009, p. 614). According to the Jyothi (2012) welfare facilities are a broad concept referring to a state of living of an individual or a group, in a desirable relationship with the total environment-ecological, economic and social. "The Welfare facilities" term includes both social and economic contents of welfare.

\subsection{Dimensions of Employee Welfare Facilities}

Opatha (2009) classified various welfare facilities such as medical facilities, canteen facilities, loan facilities, housing facilities etc. Medical facilities includes the services can be given to the employees who are sick in order to recover, such as providing information about various medical facilities 
available in the country (even foreign country), organization bears a certain percentage of the cost/bill the employee will have to bear owing to a health problem, providing medical insurance scheme etc. Canteen facilities provide facilities for food and drinks for employees. Provisions of feeding services, more likely enhances employee health. Under this there are several facilities like canteens, subsidize meal, free meals, giving certain financial allowance for food can be seen. Loan facilities are given with a view to assessing employees to celebrate various religious and social festivals (e.g., Wesak, Christmas, New Year), to hold special functions/parties (e.g., wedding) and to face unforeseen difficulties (e.g., accidents). Loan is given with an interest but interest is lower than the normal loan interest charged by banks or other financial organizations significantly. Housing facilities mean the provision of accommodation. Having a sufficient house is a strong contribution to higher standard of living, of an employee.

\section{Conceptual Framework}

Conceptual Framework is prepared by based on the literature of this study and following model (figure 1) has been developed for the purpose. The framework describes the relationships between medical facilities, canteen facilities, loan facilities, housing facilities and job satisfaction. These dimensions of welfare facilities are labeled as independent variables. Job satisfaction is labeled as the dependent variable.

\section{Welfare Facilities}

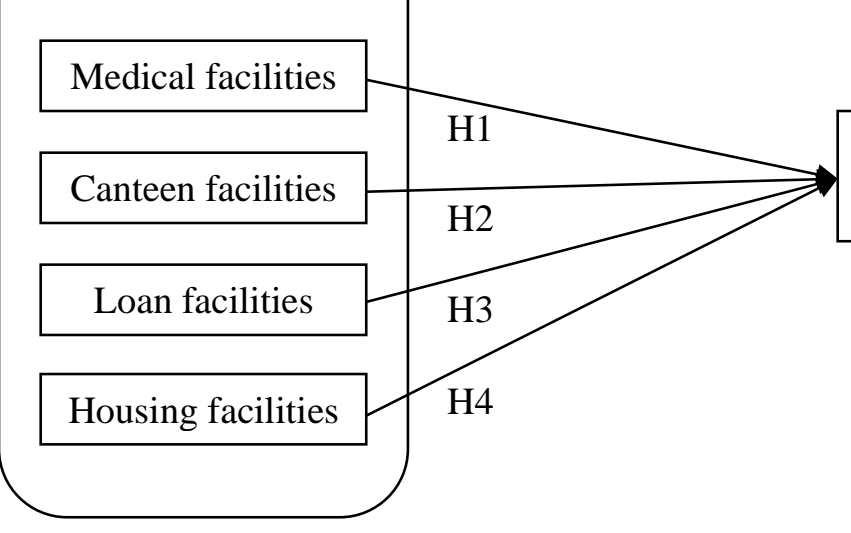

Job Satisfaction 


\section{Hypotheses Development}

Based on the above conceptual model the following hypothesis $(\mathrm{H})$ has been formulated for this study.

H1: $_{1}$ There is a significant positive relationship between medical facilities and job satisfaction.

$\mathbf{H}_{2}$ : There is a significant positive relationship between canteen facilities and job satisfaction.

H3: There is a significant positive relationship between loan facilities and job satisfaction.

H4: There is a significant positive relationship between housing facilities and job satisfaction.

\section{Research Methodology}

The sample of this study is 100 operational level employees from two leading garment manufacturing organizations in Sri Lanka. The sample is drawn from a population of 3,251 operational level employees. The sampling technique used was simple random sampling. Data collection was done by using selfadministrated structured questionnaires.

The questionnaire consists of 32 questions and the first section of the questionnaire designed to obtain demographic characteristics, including age, gender, the length of work experience etc. In the second section there are 13 questions regarding organization's welfare facilities. Finally the third section consists of 12 questions regarding job satisfaction. The questions are designed based on literature collected (Shresthya and Ganguli, 1994; Srivastava, 2002; De Souza, 2009). Some of the questions were close ended, whiles others scored on a 5-point Likert scale. Point 5 for strongly agree, 4 for agree, 3 for neutral, 2 for disagree and 1 for strongly disagree have been given in order to analyze data.

To test the hypotheses, Pearson's product moment correlation analysis, and multivariate analysis were used. The statistical computer package SPSS version 20.0 was utilized to analyze the data. 
Kelaniya Journal of Human Resource Management

Volume 11, Number 02 - July 2016

\section{Results}

\subsection{Testing Hypotheses}

The results of Pearson's product moment correlation analysis used to test the hypotheses are presented in the Table 1.

\section{Table 1: Pearson Correlation for all selected variables and job satisfaction}

\begin{tabular}{|l|c|c|c|}
\hline \multicolumn{1}{|c|}{$\begin{array}{c}\text { Independent } \\
\text { variables }\end{array}$} & Relationship & $\begin{array}{c}\text { Dependent variable } \\
\text { (Job satisfaction) }\end{array}$ & Sig. \\
\hline Medical facilities & Positive & 0.364 & 0.000 \\
\hline Canteen facilities & Positive & 0.421 & 0.000 \\
\hline Loan facilities & Positive & 0.450 & 0.000 \\
\hline Housing facilities & Positive & 0.312 & 0.000 \\
\hline
\end{tabular}

** Correlation is significant at the 0.01 level (one- tailed)

The results indicated in Table 1, the medical facilities, canteen facilities, loan facilities, housing facilities and job satisfaction have moderate positive relationships individually. Therefore hypothesis of the above mentioned variables was accepted. Further the found relationships are statistically significant, as the significant value is 0.000 which is less than the desired level of significant value of 0.01 .

Multivariate analysis evaluates the simultaneous effects of all the independent variables on dependent variable. The results of regressing the four independent variables against the dependent variable, job satisfaction are shown in the Table 2.

Table 2: Aggregate impact of the welfare facilities on job satisfaction

\begin{tabular}{|c|c|c|c|}
\hline $\mathbf{R}$ & $\mathbf{R}^{\mathbf{2}}$ & Adjusted $\mathbf{R}^{\mathbf{2}}$ & Std. error of the estimate \\
\hline 0.582 & 0.361 & 0.493 & 0.49825 \\
\hline
\end{tabular}


The adjusted square of the multiple $\mathrm{R}$ is 0.493 indicating that the $49.3 \%$ of variance in job satisfaction is explained by the four independent variables jointly.

\section{Discussion}

The sample indicated that the ages of $33 \%$ of operational level employees are in the range of $26-32$ years and $38 \%$ of the operational level employees having above 5 years of experience. Majority (84\%) of operational level employees are female. 54\% of the operational level employees are A/L Passed. When considering marital status majority (62\%) of operational level employees are married among employees considered for this study.

As hypothesized it was found that medical facilities, canteen facilities, loan facilities and housing facilities have positive relationships with job satisfaction. All the four variables are significantly correlated. The findings empirically confirm the theoretical arguments explained in the literature review. Descriptive statistics reveal that job satisfaction of operational level employees is high due to welfare facilities. These results suggest that companies should furthermore improve their welfare facilities.

\section{Conclusion}

This study mainly addressed to what extent the welfare facilities impact on job satisfaction of operational level employees in the apparel industry of Sri Lanka. The research findings give evidence that better welfare facilities lead to increased employee job satisfaction. There are several researchers expressed a number of finding relating to employee welfare facilities and job satisfaction. According to De Souza (2009), the correlation and regression analysis provide sufficient statistical evidence which were supported the relationship between employee welfare facilities and job satisfaction. Madumathi \& Desai (2003) have said that increasing employee efficiency, employee productivity and avoid the industrial dispute can be gain through providing welfare facilities to employee.

As per research finding it can be concluded that improving welfare facilities leads to increase job satisfaction of employees. Therefore the apparel industry should focus more on improving their welfare facilities. It will ultimately lead to retain their best talent within the organization. This study was limited to 
investigating the impact of welfare facilities on job satisfaction in the apparel industry of Sri Lanka. Further investigations in other types of industries may provide additional insights into the findings of the study. The findings of this research study will be important both on the theoretical level and practical level.

\section{References}

Armstrong, M. (1996). A hand book of personal management practice. London: Kogan page limited.

Baghaei, R. (2011). A comparative study of human resource management practices in private and public hospitals of Iran with special reference to job satisfaction of nurses.

De Souza, C. A. M. (2009). The employee well fare and job satisfaction: A comparative study of Indian pharmaceutical companies and multinational pharmaceutical companies in Goa. Doctoral dissertation. Goa:Khandola.

Jiskani, S. N., Bhatti, K. U. R. and Ahemed, S. (2011). Measuring Job Satisfaction Level of Government Sector Employees. Pakistan: Government of Sindh.

Jyothi, B.S. (2012).Employee Job Satisfaction in Software and ITeS units in Bangalo. An Empirical study Business Management Dynamics, 3(6):46-55.

Katuwal, S. B. and Randhwa, G. A. (2007). A study of job satisfaction of public and private sector Nepalese textile workers. Indian journal of industrial relation, 43(2):239-253.

Locke, E. A. (1976). The nature and causes of job satisfaction. Handbook of industrial and organizational psychology. Chicago: Rand McNally.

Madumati, M. and Desai, R.G. (2003). Analysis of pre and post reform social security and employee welfareexpenditures in Karnataka state road Transport Corporation. Indian journal of industrial relation, 38(4).

Opatha, H. H. D. N. P. (2009). Human resource management. Colombo: Author publication.

Park, M. (2014). Job satisfaction of social worker in senior welfare center in South Korea: the effects of individual client and organizational factors. Asian pacific journal of social work and development. 
Kelaniya Journal of Human Resource Management

Volume 11, Number 02 - July 2016

Parvin, M. M. andKabir, M.M. (2011). Factors affecting employee job satisfaction of pharmaceutical sector. Australian Journal of Business and Management Research, 1(9):113-123.

Puja, J. andSanjeev, M. (2014). Impact of voluntary welfare measureson job satisfaction: a case study of ashokleylandindia, Inernational journal of management research and busimess strategy, 3(1).

Punekar, S. D., Deodhar, S. B. and Sankaran, S. (2004). Labour welfare. Trade unionism and industrial relations.Mumbai: Himalaya Publishing House.

Reddy, K. S. (2012). Social Determinants of Cardiovascular Disease Outcomes in India. Indian Journal of Medical Research, 132(5):17-22.

Salaria, P. and Salaria, S. (2013). Employee welfare measure in auto sector. International journal of business \& management invention, 2(3):66-74.

Sathyanarayan, M. R. and Reddy R. J. (2012). A case of KCP limited. Cement industries in India, 2(7):22-29.

Schuler, R. S. (1981). Personnel and human resource management. St paul: West publishing company.

Sekaran, U. (2006). Research methods for business: a skill building approach. Wiley Indian edition. 